\title{
The Urease Activity of Fluorescent Pseudomonads
}

\author{
BY D. J. STEWART \\ Agricultural Bacteriology Department, The Queen's University of \\ Belfast and the Ministry of Agriculture for Northern Ireland
}

(Received 15 March 1965)

\begin{abstract}
SUMMARY
Media frequently used for the detection of urease activity were found to be unsuitable for fluorescent pseudomonads since the presence of free ammonia was found to suppress the formation of urease in growing cultures. Incubation of cultures for $40 \mathrm{hr}$ at $25^{\circ}$ in a low concentration Casitone + yeast-extract + glucose medium, followed by the addition of urea to $0 \cdot 2 \%$ $(w / v)$, resulted in the development of an alkaline shift in the medium after further incubation for a few more hours at $37^{\circ}$. This method gave good results in the detection of urease activity.
\end{abstract}

\section{INTRODUCTION}

De Turk (1955) recorded the adaptive (inducible) formation of urease in washed suspensions of Pseudomonas aeruginosa harvested from nutrient broth. Nevertheless Klinge (1959, 1960) defined the genus Pseudomonas as 'urease negative', Brisou (1958) found no ureolytic strains among pseudomonads from various sources and Rhodes (1959) was unable to show with certainty the possession of urease by any of 169 fluorescent pseudomonads which she examined. However, Lysenko (1961), who used essentially the same medium as Rhodes (1959), described pseudomonad isolates which apparently possessed urease activity. These workers and others used media either originally devised for use with the Enterobacteriaceae or inorganic media containing urea with or without another organic carbon source. The present work was done to evaluate the various urea media described in the literature for urease detection, and to determine whether fluorescent pseudomonads do possess urease activity and, if so, under what cultural conditions the enzyme might best be demonstrated.

\section{METHODS}

Bacteria. Fifty isolates classified as belonging to the genus Pseudomonas from hen eggs, soil, river and ditch water, milk, and chicken droppings, were examined. All were Gram-negative, polarly flagellate rods which grew well at $25^{\circ}$ but not at all at $42^{\circ}$. All oxidized glucose, were oxidase positive, penicillin resistant and produced pyoverdine (fluorescin) but not pyocyanine on the appropriate media proposed by King, Ward \& Raney (1954). Nine distinct bio-groups had been recognized among 30 of the isolates on the basis of more than 70 biochemical features (Stewart, 1964); by using the criteria proposed by Klinge $(1959,1960), 24$ of these 30 isolates were assignable to $P$. putida and the other 6 to $P$. fluorescens. Similarily 15 of the other 20 isolates were classified as $\boldsymbol{P}$. putida and the remaining 5 as $\boldsymbol{P}$. fluorescens. The organisms were maintained on nutrient agar slopes. 
Basal modified urease (MU) medium. Casitone (Difco), $0.02 \mathrm{~g}$; yeast extract (Difco), 0.02 g.; glucose, 0.05 g.; $\mathrm{NaCl}, 0.3 \mathrm{~g}$.; $\mathrm{K}_{2} \mathrm{HPO}_{4}, 0.02 \mathrm{~g}$.; distilled water $98 \mathrm{ml}$.; mixed indicator solution, $2 \mathrm{ml}$. Adjusted to $\mathrm{pH} \mathrm{7 \cdot 4}$. Sterilized for $15 \mathrm{~min}$. at $120^{\circ}$.

Glucose was chosen in preference to galactose, which was used by Rhodes (1959), because manometric studies showed that glucose was more rapidly oxidized by the isolates. The buffer salt $\left(\mathrm{K}_{2} \mathrm{HPO}_{4}\right)$ was kept at a low concentration to allow a more rapid increase in $\mathrm{pH}$ value with base production. The mixed indicator system proposed by Singer (1950) was chosen since its green colour at $\mathrm{pH} \mathbf{7 \cdot 4}$ changes to blue at about $\mathrm{pH} \mathrm{8.2}$ and to a distinct violet at about $\mathrm{pH} \mathrm{9.0,} \mathrm{thus} \mathrm{allowing} \mathrm{relative} \mathrm{degrees}$ of base production to be assessed. It consists of three indicator solutions prepared by dissolving $0.20 \mathrm{~g}$. of bromothymol blue, cresol red and thymol blue in $6.4 \mathrm{ml}$., $10.6 \mathrm{ml}$. and 8.6 ml., respectively, of $\mathrm{NaOH}(0.05 \mathrm{~N})$ and adding $100 \mathrm{ml}$. of distilled water to each solution; the three solutions are then mixed in the proportions 12.5:4:10 by vol.

Chemicals. Analar grade $\mathrm{NH}_{4} \mathrm{Cl},\left(\mathrm{NH}_{4}\right)_{2} \mathrm{SO}_{4}$ and urea (Hopkin and Williams) and $\mathbf{4 0} \%(\mathrm{w} / \mathrm{v})$ sterile urea solution (Oxoid) were used.

Delivery of $0.02 \mathrm{ml}$. amounts. Platinum-tipped dropping pipettes (Astell) were used.

Assay of urease activity in washed suspensions. To $0.40 \mathrm{ml}$. of a $0 \cdot 25 \%(\mathrm{w} / \mathrm{v})$ solution of urea (Hopkin and Williams) in veronal buffer $(0.04 \mathrm{M}, \mathrm{pH} \mathrm{7.2)}$ was added $0.10 \mathrm{ml}$. of bacterial suspension containing the equivalent of $200 \mu \mathrm{g}$. dry wt. bacteria. The ammonia released after incubation for $1 \mathrm{hr}$ at $30^{\circ}$ was estimated by the Berthelot reaction on $0.10 \mathrm{ml}$. of reactant mixture with UN Kit reagents (Hyland Laboratories, California). Endogenous and substrate ammonia were similarily determined on appropriate incubated mixtures. $\mathbf{N H}_{3}-\mathbf{N}$ values were calculated from a standard curve prepared from $\left(\mathrm{NH}_{4}\right)_{2} \mathrm{SO}_{4}$ solutions in ammoniafree distilled water.

Urease activity (qNH conditions by equiv. $1 \mathrm{mg}$. dry wt. bacteria/hr at $30^{\circ}$.

Dry weights of pseudomonad suspensions. These were determined by nephelometry and the use of a calibration curve.

\section{RESULTS}

\section{Behaviour of the pseudomonad isolates in various urea-containing media}

The following media were prepared: A (Christensen, 1946); B (Brisou, 1958); C (Stuart, van Stratum \& Rustigian, 1945); D (Ferguson \& Hook, 1943); E (Rhodes, 1959); MU medium (present paper). Their compositions are given in Table 1. The various media were inoculated, with a straight wire, from nutrient agar cultures of the 50 isolates and incubated at $25^{\circ}$. Daily for the first 14 days and then every few days for a total of 42 days, the tubes were examined for growth and change in $\mathrm{pH}$ value. The results (Table 2 ) clearly showed that media B, C and D were unsuitable for the growth of all but a few of the isolates. Most of the isolates grew in medium $\mathbf{E}$ although only 3 of 45 of these gave an alkaline reaction. All the isolates grew well in medium A to produce in most cases (45/50) a slow alkaline reaction. Forty of these 45 isolates, however, gave a similar reaction in this medium even when the urea was omitted, a phenomenon earlier reported by Rhodes (1959), and one which renders medium $\mathbf{A}$ useless in testing such organisms for urease activity. 
Table 1. Urea-containing media

Composition of the five urea-containing media examined: A (Christensen, 1946); B (Brisou, 1958); C (Stuart et al. 1945); D (Ferguson \& Hook, 1943); E (Rhodes, 1959); MU (present paper)

Percentage $(w / v)$ composition in medium:

\begin{tabular}{|c|c|c|c|c|c|c|}
\hline Constituent & A & $\mathbf{B}$ & $\mathbf{C}$ & $\mathbf{D}$ & $\mathbf{E}$ & MU \\
\hline Peptone (Oxoid L37) & $0 \cdot 1$ & - & - & - & - & $\begin{array}{c}0.02 \\
\text { (Casitone) }\end{array}$ \\
\hline $\mathrm{NH}_{4} \mathrm{H}_{2} \mathrm{PO}_{4}$ & - & - & - & - & $0 \cdot 1$ & - \\
\hline Yeast extract (Difco) & - & - & 0.01 & - & -- & 0.02 \\
\hline Glucose & $0 \cdot 1$ & - & - & - & - & 0.05 \\
\hline Galactose & - & - & - & - & $0 \cdot 1$ & - \\
\hline Ethanol & - & - & & $1 \cdot 0$ & - & - \\
\hline $\mathrm{KH}_{2} \mathrm{PO}_{4}$ & 0.2 & $0 \cdot 1$ & 0.91 & $0 \cdot 1$ & - & - \\
\hline $\mathrm{K}_{2} \mathrm{HPO}_{4}$ & - & $0 \cdot 1$ & - & $0 \cdot 1$ & - & 0.02 \\
\hline $\mathrm{Na}_{2} \mathrm{HPO}_{4}$ & - & - & 0.95 & - & - & - \\
\hline $\mathrm{NaCl}$ & 0.5 & - & - & 0.5 & - & $0 \cdot 3$ \\
\hline $\mathrm{KCl}$ & - & - & - & - & $0 \cdot 02$ & - \\
\hline $\mathrm{MgSO}_{4} \cdot 7 \mathrm{H}_{2} \mathrm{O}$ & - & - & - & - & 0.02 & - \\
\hline Agar & $\mathbf{2 \cdot 0}$ & - & - & - & - & - \\
\hline Urea (Oxoid) & $2 \cdot 0$ & $2 \cdot 0$ & $\mathbf{2 \cdot 0}$ & $2 \cdot 0$ & $\mathbf{2 \cdot 0}$ & {$[0 \cdot 2]^{*}$} \\
\hline Indicator & PR & BTB & PR & PR & PR & $\mathbf{s}$ \\
\hline Initial pH & $6 \cdot 8$ & $7 \cdot 0$ & 6.8 & $7 \cdot 0$ & $7 \cdot 0$ & $7 \cdot 4$ \\
\hline
\end{tabular}

PR = Phenol red; BTB = Bromothymol blue; $S=$ Singer (1950).

* Added after culture incubated at $25^{\circ}$ for $44 \mathrm{hr}$.

Table 2. Behaviour of the 50 pseudomonad isolates in the urea-containing media

Showing the proportion of isolates able to grow and to produce an alkaline reaction in media : A (Christensen, 1946); B (Brisou, 1958); C (Stuart et al. 1945); D (Ferguson \& Hook, 1943); E (Rhodes, 1959)

$\begin{array}{cccc}\text { Medium } & \begin{array}{c}\text { Proportion } \\ \text { able to } \\ \text { grow }\end{array} & \begin{array}{c}\text { Proportion } \\ \text { producing } \\ \text { an alkaline } \\ \text { reaction }\end{array} & \begin{array}{c}\text { Time for an } \\ \text { alkaline } \\ \text { reaction } \\ \text { to develop } \\ \text { (weeks) }\end{array} \\ \text { A } & 50 / 50 & 45 / 50 & 3-4 \\ \text { B } & 8 / 50 & 8 / 8 & 3-4 \\ \text { C } & 5 / 50 & 0 / 5 & - \\ \text { D } & 7 / 50 & 7 / 7 & 3-4 \\ \text { E } & 45 / 50 & 3 / 45 & 2-3\end{array}$

Behaviour of the pseudomonad isolates in $M U$ medium containing various concentrations of urea

Urea (Oxoid) was added aseptically to batches of sterile basal MU medium $(\mathrm{pH} 7 \cdot 4)$ to final concentrations $(\%, \mathrm{w} / \mathrm{v})$ of: $0,0 \cdot 05,0 \cdot 1,0 \cdot 2,0 \cdot 5,1 \cdot 0,2 \cdot 0$. These media were dispensed in $2 \mathrm{ml}$. amounts into test tubes $(100 \mathrm{~mm} . \times 10 \mathrm{~mm}$.) and inoculated with $0.02 \mathrm{ml}$. of dilute suspensions of organisms in $\frac{1}{4}$-strength Ringer's solution prepared from nutrient agar cultures of 6 of the isolates ( 3 classified as Pseudomonas putida, 3 as $\boldsymbol{P}$. fluorescens). These cultures were incubated for 14 days at $25^{\circ}$ with daily examination for growth and change in $\mathrm{pH}$ value.

The 6 isolates grew well in all seven media; the results with one of them (S. 60) typical of the 6, are shown in Table 3. It appeared that urea concentrations greater 
than $0.2 \%$ in the MU medium delayed the change to a more alkaline $\mathrm{pH}$ value. All 50 isolates were then tested by growth in the $0.2 \%$ urea $\mathrm{MU}$ medium; they all produced a blue colour within 7 days and a violet one within 12 days. In the MU medium without urea, all the isolates caused a slight but permanent acid change (yellow-green, $\mathrm{pH} \mathrm{6.5)}$ ) after incubation for a day or two.

\section{Table 3. Reactions of pseudomonad strain $S .60$ in the $M U$ media}

The time (in days) for the pH value to increase to 8.2 (indicator blue) and to $9 \cdot 0$ (indicator violet) in the MU media containing $(\%, w / v): 0,0 \cdot 05,0 \cdot 1,0 \cdot 2,0.5,1.0,2 \cdot 0$ urea, inoculated with strain S. 60 and incubated at $25^{\circ}$.

\begin{tabular}{|c|c|c|}
\hline \multirow[b]{2}{*}{$\begin{array}{l}\text { Percentage } \\
(w / v) \text { urea } \\
\text { in medium }\end{array}$} & \multicolumn{2}{|c|}{$\begin{array}{c}\text { Days for alkaline reactio } \\
\text { to develop }\end{array}$} \\
\hline & $\begin{array}{c}\text { pH 8.2 } \\
\text { (blue) }\end{array}$ & $\begin{array}{l}\text { pH 9.0 } \\
\text { (violet) }\end{array}$ \\
\hline 0 & n. al.* & n. al. \\
\hline 0.05 & $\mathbf{3}$ & 5 \\
\hline $0 \cdot 1$ & $\mathbf{3}$ & 5 \\
\hline 0.2 & 3 & 5 \\
\hline 0.5 & 4 & 6 \\
\hline 1.0 & 5 & 10 \\
\hline $\mathbf{2} \cdot 0$ & 5 & 10 \\
\hline
\end{tabular}

* n. al. = no alkaline reaction developed within 14 days.

Table 4. Urease activities $\left(q \mathrm{NH}_{\mathrm{3}}-\mathrm{N}\right)$ of pseudomonad strain $\mathrm{S} .1$ incubated in MU media with and without urea

\begin{tabular}{|c|c|c|c|}
\hline \multirow[b]{2}{*}{$\begin{array}{c}\text { Age of } \\
\text { culture } \\
\text { (days) }\end{array}$} & \multicolumn{3}{|c|}{$\mathrm{qNH}_{3}-\mathrm{N}$ of bacteria harvested from: } \\
\hline & $\begin{array}{c}\text { MU } \\
\text { medium }\end{array}$ & $\underset{\text { urea }}{\text { MU }} \underset{\text { medium }}{\mathbf{0 . 2} \%}$ & $\begin{array}{c}\text { MU } \\
\text { urea }\end{array}$ \\
\hline $\mathbf{1}$ & $\mathbf{5} \cdot \mathbf{1}$ & $0 \cdot 4$ & $0 \cdot \mathbf{3}$ \\
\hline 2 & $25 \cdot 3$ & $1 \cdot 2$ & 0.5 \\
\hline 4 & $\mathbf{3 2 \cdot 0}$ & 4.5 & $0 \cdot 9$ \\
\hline 6 & $84 \cdot 1$ & $4 \cdot 4$ & 1.2 \\
\hline
\end{tabular}

The development and activity of pseudomonad urease in $M U$ media

Modified basal MU medium with $0.4 \%(w / v) \mathrm{K}_{2} \mathrm{HPO}_{4}$ and without indicator was prepared. Batches containing: no urea, $0 \cdot 2 \%(\mathrm{w} / \mathrm{v})$ urea (Oxoid) and $2 \%(\mathrm{w} / \mathrm{v})$ urea (Oxoid), respectively, were dispensed in $100 \mathrm{ml}$. amounts in round bottles of $230 \mathrm{ml}$. capacity. A dilute suspension of one of the pseudomonad isolates (S. 1) was inoculated ( $1 \mathrm{ml}$.) to each of four bottles of the three MU media $(0,0.2,2 \%$ urea). After incubation for $1,2,4$ and 6 days at $25^{\circ}$, the crop of isolate $S$. 1 was harvested by centrifugation from, on each occasion, one bottle of each of the three media. The various lots of deposited organisms were washed twice in distilled water, each resuspended to $1 \mathrm{ml}$. in veronal buffer $\left(0.04 \mathrm{M}, \mathrm{pH} \mathrm{7.2)}\right.$ and held at $-20^{\circ}$ for urease assay. The urease activities $\left(\mathrm{qNH}_{3}-\mathrm{N}\right)$ of the suspensions are shown in Table 4. The bacteria grown in the absence of urea showed significant urease activity which increased greatly with the time of incubation of the cultures. Very little urease was formed in the bacteria grown in the $0.2 \%$ urea medium and even less in the $2 \%$ 
urea medium. It was concluded that urea added to MU medium exerted a considerable inhibitory effect on the formation of urease.

The effect of urea and of ammonia on the development of urease

Organisms of pseudomonad strain S. 1 were harvested after growth for 6 days in MU media containing (w/v): (1) $0.0038 \% \mathrm{NH}_{4} \mathrm{Cl}$ (equivalent to $10 \mu \mathrm{g}$. $\mathrm{NH}_{3}-\mathrm{N} / \mathrm{ml}$.); (2) $2 \%$ Oxoid urea; (3) $2 \%$ Hopkin and Williams urea (urea added as a Seitz-filtered solution). Urease activities of the organisms and the supernatant $\mathrm{NH}_{3}-\mathrm{N}$ concentrations of the culture fluids before and after incubation were measured. It can be seen from Table 5 that little or no ammonia disappeared from any of the media during incubation. The results indicated that the low concentration of glucose $(0.05 \%, \mathrm{w} / \mathrm{v})$ in the medium was insufficient to allow the assimilation of any more nitrogen than was already provided in organic forms in the peptone and yeast extract and that the presence of very low concentrations of unassimilable $\mathrm{NH}_{3}-\mathrm{N}$ was sufficient to suppress urease formation by the growing bacteria.

Table 5. Ammonia-N assimilation by, and urease activity of pseudomonad strain $S .1$ grown in $\mathrm{MU}$ media with or without the addition of $\mathrm{NH}_{4} \mathrm{Cl}$ or urea

Urease activity $\left(\mathrm{qNH}_{3}-\mathrm{N}\right)$ of organism $\mathrm{S}$. 1 harvested from, and the $\mathrm{NH}_{\mathbf{a}}-\mathrm{N}$ concentrations in the culture supernatant fluids of, MU medium with and without urea.

$\quad$ Medium
MU (no addition)
MU + $0 \cdot 0038 \% \mathrm{NH}_{4} \mathrm{Cl}$
MU $+2 \%$ Oxoid urea
MU $+2 \%$ Hopkin and Williams urea

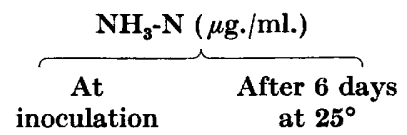

$1 \cdot 0$

$10 \cdot 1$

$38 \cdot 0$

$\mathbf{3 \cdot 0}$ at $\mathbf{2 5}^{\circ}$

$0 \cdot 9$
$9 \cdot 7$

$\mathbf{3 6 \cdot 5}$

14.0

$\mathrm{qNH}_{3}-\mathrm{N}$
104
$<1$
$<1$
$<1$

Technique adopted for demonstrating urease activity in fluorescent pseudomonads

On the basis of the above results, the following procedure was used to examine urease production by the $\mathbf{5 0}$ pseudomonad isolates. The isolates were inoculated by a straight wire from nutrient agar cultures into $2 \mathrm{ml}$. of basal MU medium (in $100 \mathrm{~mm} . \times 10 \mathrm{~mm}$. tubes). After incubation for $40 \mathrm{hr}$ at $25^{\circ}$, good growth was apparent in all the tubes and the $\mathrm{pH}$ values had decreased to about $6 \cdot 5$. To each tube was then added aseptically $0.02 \mathrm{ml}$. of $20 \%(\mathrm{w} / \mathrm{v})$ urea solution, the tubes were shaken and re-incubated at $37^{\circ}$. Alkalinity developed within a few hours in all tubes; in no case did the incubation period for a $\mathrm{pH}$ value of $9 \cdot 0$ (violet) to be reached exceed $6 \mathrm{hr}$.

In addition to these 50 isolates, all of 25 isolates of Pseudomonas aeruginosa from clinical specimens and milk were found by this technique to hydrolyse urea actively (with these organisms the initial incubation for growth was at $37^{\circ}$ ). 


\section{REFERENCES}

Brisou, J. (1958). Étude de quelques Pseudomonadaceae. Bordeaux: Baillet.

Christensen, W. B. (1946). Urea decomposition as a means of differentiating Proteus and paracolon organisms from each other and from Salmonella and Shigella types. J. Bact. 52, 461 .

Ferguson, W. W. \& Hook, A. E. (1943). Urease activity of Proteus and Salmonella organisms. J. Lab. clin. Med. 28, 1715.

King, E. O., WARD, M. K. \& RANey, D. E. (1954). Two simple media for the demonstration of pyocyanin and fluorescin. J. Lab. clin. Med. 54, 301.

KuInge, K. (1959). Pseudomonas fluorescens, ein Boden- und Wasserkeim. I. Physiologie und Identifizierung. Arch. Mikrobiol. 33, 1.

KLINGE, K. (1960). Differential techniques and methods of isolation of Pseudomonas. J. appl. Bact. 23, 442.

Lxsenko, O. (1961). Pseudomonas-an attempt at a general classification. J. gen. Microbiol. 25, 379.

Rhodes, M. E. (1959). The characterization of Pseudomonas fluorescens. J. gen. Microbiol. 21, 221.

Singer, J. (1950). Culture of Enterobacteriaceae. I. A practical medium containing urea, tryptone, lactose and indicator. Amer. J. clin. Path. 20, 880.

StEwart, D. J. (1964). A study of the pseudomonads responsible for 'green-rot' of the avian egg. Ph.D. Thesis, Queen's University, Belfast.

Stuart, C. A., van Stratum, E. \& Rustigian, R. (1945). Further studies on urease production by Proteus and related organisms. J. Bact. 49, 437 .

DE TURK, W. E. (1955). The adaptive formation of urease by washed suspensions of Pseudomonas aeruginosa. J. Bact. 70, 187. 